\title{
O “São Frei Gil”, de Eça de Queirós
}

\author{
The "São Frei Gil", by Eça de Queirós \\ Antonio Augusto Nery* \\ Universidade Federal do Paraná (PRINT/CAPES/CIDH/CLEPUL) \\ Curitiba, Paraná, Brasil \\ Eduardo Soczek Mendes* \\ Universidade Estadual do Centro-Oeste/ Universidade Federal do Paraná \\ Guarapuava, Paraná, Brasil
}

\begin{abstract}
Resumo: Eça de Queirós (1845-1900) é muito conhecido pelos seus romances, entretanto o autor se dedicou à elaboração de muitos outros gêneros textuais, como o conto e a crônica, e até mesmo reelaborou histórias de santos. Visto que são três as revisitações hagiográficas de Eça, neste estudo, averiguaremos uma delas, a que está inacabada "São Frei Gil". Essas narrativas, escritas durante a última década de vida, vieram a público postumamente, em 1912, em Últimas páginas. Em "São Frei Gil”, Eça retoma a lenda egidiana, preexistente em Portugal, ambientando na Idade Média a história do santo que pactuou com o Diabo. Nossa proposta é a de analisar a forma como a narrativa é construída e, se é possível, com efeito, afirmar que o escritor, ao fim de sua vida, havia se acomodado e se resignado com o velho Portugal e com os poderes instituídos, deixando de lado a escrita irônica para dar vazão a uma produção de enaltecimento pátrio. Para tanto, verificaremos de que maneira se realizou o diálogo com a tradição pregressa da lenda e como o narrador discorre acerca de Gil, da ambientação e de outras personagens. Dialogaremos, sobretudo, com as propostas de Antonio Candido (1964), Ian Watt (1997) e Sofia de Sousa Silva (2002).
\end{abstract}

Palavras-chave: Eça de Queirós. Hagiografia. São Frei Gil.

\begin{abstract}
Eça de Queirós (1845-1900) is much better known for his novels, however the author devoted himself to elaborating many other textual genres, such as the short story and the chronicle, and even reworked saints' stories. Since there are three hagiographic revisits of Eça, in this study, we will investigate one of them, the unfinished "São Frei Gil". These narratives, written during the last decade of life, were made public posthumously in 1912 in the Last Pages. In "São Frei Gil”, Eça takes up the egidian legend, pre-existing in Portugal., Setting in the Middle Ages the story of the saint who agreed with the Devil. Our proposal is to analyze the way the narrative is constructed and, if it is possible, in fact, to affirm that the writer, at the end of his life, had settled down and resigned himself to the old Portugal and to the instituted powers, leaving it to him. aside the ironic writing to give vent to a production of exalting country. To this end, we will see how the dialogue with the previous tradition of the legend took place and how the narrator talks about Gil, the ambiance and other characters. We will talk, above all, with the proposals of Antonio Candido (1964), Ian Watt (1997) and Sofia de Sousa Silva (2002).
\end{abstract}

Keywords: Eça de Queirós. Hagiography. São Frei Gil.

* Doutor em Letras (Literatura Portuguesa) pela Universidade de São Paulo. Professor Associado de Literatura Portuguesa da Universidade Federal do Paraná. Entre 2019 e 2020 é Professor Visitante na Cátedra Infante Dom Henrique/Centro de Literaturas e Culturas Lusófonas e Europeias da Universidade de Lisboa, como Bolsista do Programa de Internacionalização da Universidade Federal do Paraná/Coordenação de Aperfeiçoamento de Pessoal de Nível Superior (CAPES). O presente trabalho foi realizado com apoio da CAPES/Brasil - Código de Financiamento 001. E-mail: gutonery@hotmail.com.

* Doutorando em Letras (Estudos Literários) pela Universidade Federal do Paraná. Mestre em Letras (Estudos Literários) pela mesma instituição. Professor de Teoria da Literatura e Literatura Portuguesa da Universidade Estadual do Centro-Oeste, Campus Santa Cruz, Guarapuava. E-mail: edu.soczek@gmail.com. 


\section{INTRODUÇÃO}

O escritor português Eça de Queirós (1845-1900) é muito conhecido pelos seus romances vinculados à estética Realista, tais como O crime do padre Amaro publicado em três diferentes versões ${ }^{1}$-, O primo Basílio, de 1878, ou Os Maias, que veio a lume em 1888. Contudo, na última década de vida, o autor se dedica à escrita da vida de três santos, interesse que poderia se entender díspar, se comparado a obras publicadas anteriormente, seja pelo gênero textual, seja pelo teor crítico, incluindo textos com a deflagrada temática (anti)religiosa, como o conto "A morte de Jesus" (1869); o já citado O crime do Padre Amaro e A relíquia (1887). "Em volume póstumo das obras de Eça de Queirós (1912), Luís de Magalhães reuniu textos inéditos, intitulando-o Últimas páginas, dos quais apenas um quinto não se incluía nas Lendas de Santos." (BERARDINELLI, 2002, p. 7) ${ }^{2}$. Um tipo de obra que, possivelmente, era muito inesperada na escrita de "Eça, o irônico. Eça, o crítico da sociedade portuguesa. Eça, o escritor anticlerical." (SILVA, 2002, p. 245) veio a lume graças ao trabalho de edição de Magalhães (1859-1935). Sobre o contexto de produção de "Santo Onofre", "São Cristóvão" e "São Frei Gil" pouco se sabe de efetivo e é muito possível que tenham sido lavradas nos primeiros anos da década de $1890^{3}$.

O fato é que Eça de Queirós não foi o único ou o primeiro a mencionar ou reelaborar as hagiografias de santos. Tratando especificamente da lenda de São Frei Gil, Rui Lopo (p. 276) enumera, para além de Queirós,

[...] a título meramente ilustrativo, a Egideia, de José Pedro Xavier do Monte (1788); [...] Garrett nas Viagens [na minha terra] e em Dona Branca; [...] Frei Gil de Santarém - Lenda faustiana da Primeira Renascença, de Teófilo Braga, As tentacões de Frei Gil, de António Correia, e de João Grave, São Frei Gil de Santarém - Homem do Diabo e de Deus.

Porém, embora o romance de Almeida Garrett (1799-1854), Viagens na minha terra (1846), seja citado por Lopo, não há uma recontagem da história do santo, mas o narrador apenas visita a Santarém e o extinto convento de São Domingos, onde deveriam jazer os restos mortais de São Frei Gil e reclama: "Nós precisamos de

\footnotetext{
${ }^{1}$ Maria Filomena Mónica (2001, p. 157) refere que “[...] O crime do padre Amaro não constitui uma obra, mas três: $O$ crime de 1875 , o de 1876 e o de 1880 . Não apenas pela diferença na dimensão - a primeira tinha 136 páginas, a segunda, 362, e a terceira, 674 - como, o que é mais significativo, pela evolução na abordagem do tema", já que a primeira edição havia sido publicada sem o consentimento de Eça e as outras passaram por alterações significativas.

2 Optamos por manter a ortografia nas transcrições conforme as edições que consultamos.

${ }^{3}$ Sofia de Sousa Silva (2002, p. 251) discorre que "Não se sabe com exatidão a data da escrita das lendas. [...] as referências às lendas são escassas. Numa carta a Oliveira Martins, datada de 10 de maio de 1884, o autor faz uma breve menção ao projeto de escrever as vidas dos grandes santos. Numa outra carta a Oliveira Martins, datada de 17 de abril de 1893, já tendo abandonado a lenda de são frei Gil, Eça afirma estar-se dedicando a escrever a lenda de Santo Onofre”. Discute-se, mais profundamente, sobre a data de escrita das obras coligidas em Últimas páginas no texto São Frei Gil (Eça de Queirós): entre a santidade e a "ambição de tudo saber" (NERY, 2013).
} 
alguém que nos cante as admiráveis lutas - ora cômicas, ora tremendas - do nosso Frei Gil de Santarém com o diabo. [...] é necessário que apareça como protagonista de uma grande ação, pintado de corpo inteiro, na primeira luz, em toda a luz do quadro" (GARRETT, 1977, p. 129). Obviamente, o retrato de São Frei Gil sob a escrita garrettiana merece o seu devido estudo, mas é possível afirmar que Eça tenha tentado dar o retrato literário que faltava, de acordo com o narrador de Viagens na minha terra, ao santo português. Se não logrou o total êxito, já que a obra ficou inconclusa antes mesmo de haver um real embate entre o santo e o Diabo - o manuscrito termina na parte em que Gil, ainda não frade, é conduzido pela personificação do Diabo, o Senhor de Astorga, a Toledo -, Eça de Queirós mergulhou numa tradição popular longínqua e formulou uma narrativa que merece ser analisada com critérios que dialoguem com o restante da obra queirosiana, com a tradição popular portuguesa e com as tradições hagiográficas oficializadas pela Igreja Católica.

A nossa proposta, neste estudo, além de perceber o teor crítico presente no texto, busca investigar como se deu a reelaboração do mito egidiano ${ }^{4}-$ da contagem da vida de São Frei Gil - sob a pena do autor português, verificando se há a preservação da fórmula hagiográfica tradicional na revisitação de Eça de Queirós. E, por fim, pensaremos em como os escritos do fim da vida do autor foram lidos posteriormente pela crítica e em determinados momentos históricos. Entretanto, antes da análise do texto queirosiano, se faz necessária a retomada do mito egidiano, sobretudo no que se refere ao seu mote principal: o pacto com o Diabo e a permanência desse topos em termos literários.

\section{LENDA EGIDIANA E PACTO DIABÓLICO: SÃO FREI GIL, O FAUSTO PORTUGUÊS?}

Em Viagens na minha terra, de Garrett, o narrador compara Frei Gil ao Fausto, quando menciona o Convento de S. Domingos, em Santarém, "[...] célebre pelo jazigo do nosso Fausto português” (GARRETT, 1974, p. 98). Teófilo Braga (18431924) e João Grave (1872-1934), por exemplo, também realizam tais comparações em As tentações de Frei Gil e São Frei Gil de Santarém - Homem do Diabo e de Deus, respectivamente. Não discutiremos com profundidade as semelhanças e as diferenças entre o mito português e o alemão, mas é fato que elas existem. Tomemos, para nos situarmos, as informações acerca do Fausto propostas por Ian Watt:

Fausto [...] começa, indubitavelmente, com uma pessoa real e histórica. Infelizmente, embora haja muitos registros contemporâneos de suas atividades, eles são também por demais insuficientes, e assim não sabemos de fato que tipo de pessoa era o Fausto original. / Na Alemanha das quatro primeiras décadas do século XVI era largamente conhecido um mágico errante que atendia pelo nome de Jorge (Jörg em alemão,

\footnotetext{
${ }^{4} \mathrm{O}$ termo egidiano está relacionado com o nome de São Frei Gil, que em algumas fontes figura com o nome de Egídio.
} 
Georgius em latim) Faust ou Faustus; às vezes ele era mencionado simplesmente como Doutor Faust [Fausto]. Seu nascimento ocorreu possivelmente por volta de 1480, na pequena cidade de Knittlingen, no norte do Württemberg; e é provável que tenha morrido pela altura de 1540, ao que indica em Staufen [...]. / Há umas treze referências contemporâneas a esse Jorge Fausto. (WATT, 1997, p. 19)

Uma das primeiras distinções entre Frei Gil e Fausto é o período e o lugar em que viveram. Porém, de forma semelhante ao mito alemão, as informações acerca do homem Gil são imprecisas, mas há um consenso de que realmente existiu. Segundo Lopo (2013, p. 268), "Frei Gil de Santarém nasce presumivelmente em Vouzela em finais do século XII, e terá morrido em Santarém, em 1265, no dia da Ascensão. Seu pai, Rodrigo, ou Rui, de Valadares, terá sido Alcaide-Mor de Coimbra”. Ou seja: é historicamente anterior a Fausto. $O$ autor ainda afirma que, mesmo que as informações sejam incertas, dão-nos um quadro geral das informações relacionadas à biografia do santo (LOPO, 2013, p. 268), pois, a mais antiga fonte hagiográfica que chegou até nós data de 1537, embora exista um documento contemporâneo a Frei Gil, de 1258, a Vita Fratrum, dos Dominicanos, que registra os feitos dos membros da Ordem (LOPO, 2013, p. 277). Ainda assim, segundo o crítico, “[...] é quase impossível pretender reconstruir uma biografia histórica de um personagem lendariamente caracterizado" (LOPO, 2013, p. 272).

Das particularidades do santo português, Lopo (2013, p. 268) afirma que "Frei Gil terá, durante a sua vida, viajado por duas vezes a Paris, onde terá primeiro estudado Medicina e depois Teologia". Devemos recordar, no entanto, que para o estabelecimento de um santo popular, como é o caso de São Frei Gil, “A história factual tem pouco valor no interior da aldeia, onde é a memória colectiva e o consenso simbólico que importa" (ESPÍRITO SANTO, 1984, p. 25). Nesse sentido, Moisés Espírito Santo esclarece que

Um santo só existe pela vontade de seus fiéis e ele é o que a aldeia ou o grupo de fiéis
quer que ele seja. Este é um princípio importante do seu culto, que tem apenas uma
longínqua relação com a mesma personagem da liturgia católica. O santo não é mais do
que um nome, uma imagem e uma lenda, ou por outras palavras, é um símbolo, uma
norma de conduta ou um modelo onde reflectem os valores sociais. [...] o culto dos
santos é justificado por uma narrativa lendária. (ESPÍRITO SANTO, 1984, p. 116).

Se tomarmos as considerações de Espírito Santo, veremos que o caso de São Frei Gil fica ainda mais complexo: existe, pois, a pessoa histórica, mas também existe o discurso religioso oficial sobre a santidade de tal pessoa e, para além, existem as múltiplas figurações legendárias e populares do santo. Fica então, ainda mais intrincada a relação da dificuldade em afirmar o que é um fato histórico e o que pode ser mítico.

Há ainda uma peculiaridade levantada por Lopo, que é a dúvida se Frei Gil era um moçárabe ${ }^{5}$, identidade muito particular, relacionada à Península Ibérica. Sobre

\footnotetext{
${ }^{5}$ Fortunato de Almeida (1967, p. 71, grifos do autor) explica que "Com o nome de moçárabes
} designavam os sarracenos os povos que, sem abandonarem a própria religião, recebiam o jugo 
isso, o autor menciona as traduções, do árabe, de livros de medicina que são atribuídas ao santo português (LOPO, 2013, p. 268) e o pedido de um superior da Ordem dos Pregadores - os Dominicanos - para que Frei Gil instituísse uma escola de língua árabe em Santarém (LOPO, 2013, p. 271).

Mas, foi, certamente, a principal semelhança entre o santo português e o mito fáustico que levou a alguns escritores a compararem São Frei Gil ao Doutor Fausto: o possível pacto diabólico e "[...] pecadores, é claro, são sempre mais interessantes do que santos" (WATT, 1997, p. 15). Sabemos que, na produção ficcional, abundam exemplos de personagens que pactuaram - ou talvez teriam pactuado - com o Diabo: as obras primas do alemão Johann Wolfgang von Goethe (1749-1832), do irlandês Oscar Wilde (1854-1990) e do brasileiro João Guimarães Rosa (1908-1967), Fausto, uma tragédia (1808), O retrato de Dorian Gray (1890) e Grande Sertão: Veredas (1956), respectivamente, são exemplos disso. Incontáveis, além do mais, na Literatura Ocidental, são as narrativas que figuram o Diabo como personagem.

Entretanto, até mesmo pela distância temporal entre Frei Gil e Doutor Fausto, há uma distinção entre os pactos que teriam firmado com o Diabo. De acordo com Lopo (2013, p. 271, grifos do autor), o santo português foi para "[...] Toledo onde, durante sete anos, segundo reza a lenda hagiográfica, frequenta uma espécie de Universidade Infernal, em cavernas, onde teria aprendido as ciências necromantes e diabólicas”. Eça de Queirós, em sua reelaboração da lenda do santo, no manuscrito por concluir, encerra com a partida de Gil, acompanhando um Senhor de Astorga, que sugeriu a ida à terra de Toledo, ao invés de Paris:

- [...] E para onde vos ides assim, em tão longa jornada? / - A Paris, Senhor d'Astorga. /O Senhor d'Astorga moveu lentamente a cabeça: / - Grande cidade, fina cidade... Bons amigos lá tenho! Na Côrte e nas Escolas. [...] Para o grande saber, só ha na terra uma escola, e essa em Toledo. (QUEIROZ, 1921, p. 332)

Ou seja, de fato, Eça preserva, em sua narrativa, os elementos tradicionais da hagiografia de São Frei Gil. E a personagem do Senhor de Astorga ainda, sob a pena de Eça, instiga o jovem, discursivamente, com promessas de grande fama:

- Que pretendeis vós aprender? / - As artes medicas. / O Senhor d'Astorga encolheu os hombros, com largo e risonho desdem: / - Oh! para isso de certo tendes em Paris mestres que bastem. E mesmo em Zamora encontrareis o bom Physico arabe Reimão Esterravia! E até na vossa Coimbra tendes homem professo, que tudo vos podia

muçulmano. Moçárabe deriva de Mocetárabe, que significa feitos ou tornados árabes". Os muçulmanos passaram a dominar a Península Ibérica a partir do século VIII, pois "A monarquia visigótica veio a acabar pela invasão árabe no tempo do rei Rodrigo, que se apoderara do trono com o favor dos nobres, por não quererem estes reconhecer o filho de Vitiza (710)." (ALMEIDA, 1967, p. 69). É complexo o período de quase 800 anos de presença islâmica no território, já que os reinos muçulmanos não eram unificados e, muitos deles, possuíam rixas internas. Também as fronteiras desses reinos árabes foram diferentes e oscilaram em determinados momentos. Contudo, também houve convivência harmoniosa entre membros muçulmanos e cristãos nos períodos e territórios dominados pelo Islão. Um dos objetivos, porém, do primeiro rei de Portugal (séc. XII) foi a conquista dos territórios que estavam sob o domínio muçulmano, como as cidades de Lisboa, Santarém e Sintra. 
ensinar [...] Mas vós, Senhor D. Gil, um moço de tão boa feição, d'altos espiritos, que de certo amaes a fama, como vos quereis amesquinhar em saber tão mesquinho? (QUEIROZ, 1921, p. 332-333).

O trecho transcrito já revela uma sutil tentação ao jovem Gil: o Senhor de Astorga o oferece sucesso e fama, mas, para isso, ele deveria deixar de ir a Paris. Embora o jovem tivesse os nobres anseios de espalhar, com a sua formação, o bem entre as pessoas, a ambição da grande fama já estava presente em Gil muito antes do aparecimento do Senhor de Astorga, conforme revela o seguinte excerto: "[...] tinha a ambição da gloria, de honrar o seu nome, e de espalhar o bem pelo mundo: [...] e depois de muito cogitar, decidira que o seu desejo se satisfaria indo estudar ás escolas de França, para voltar ao reino, como um grande escolar em medicina" (QUEIROZ, 1921, p. 319). Podemos mencionar ainda que o Senhor de Astorga e o seu escudeiro, Harbrico, são personificações estereotipadas do Diabo: "Com os dedos gordos, que findavam em unhas muito agudas e curvas, o Senhor d'Astorga aguçava a ponta da barba" (QUEIROZ, 1921, p. 329) ou "O Senhor d'Astorga alçou com solemnidade as suas espessas sobrancelhas, alargou os olhos claros" (QUEIROZ, 1921, p. 332). Essas características físicas, dentro da economia da narrativa queirosiana, já levam o leitor às referências da estereotipia do Demônio, embora o jovem Gil não dê conta, inicialmente, com quem está tratando.

Todavia, de acordo com Lopo, no restante dos relatos hagiográficos tradicionais - que Eça de Queirós não chegou a reelaborar em sua obra inconclusa a conversão de Gil figurava como ponto crucial:

Após a estadia em Toledo, seguir-se-ia o arrependimento, a entrada na Ordem Dominicana e a adopção de uma atitude existencial marcada pela humildade, a vitória sobre as tentações, a estadia no convento de Santarém, a recuperação da cédula, por intercessão da Virgem, onde constava o comprometimento espiritual com o demónio, a nova viagem a Paris para aprender Teologia, a assumpção ao cargo de Provincial, as mortificações, os êxtases e visões e os milagres antes e depois da morte. (LOPO, 2013, p. 271)

E essa é uma das suas principais distinções com o Doutor Fausto: a conversão e a anulação do pacto com o Diabo, pelo intermédio da Virgem, enquanto que "O pacto assinado no Faustbuch permite ao próprio Diabo agarrar sua presa, e em um dia preestabelecido" (WATT, 1997, p. 40). Ou seja, no mito de Doutor Fausto não há o resgate de sua pessoa como há com o santo dominicano. O Faustbuch era uma das obras didáticas publicadas na Alemanha após a Reforma Protestante (séc. XVI) e que, embora fosse ficcional, vinha a lume como literalmente verdadeira, na tentativa de apresentar lições morais (WATT, 1997, p. 37-38) de que o envolvimento com o Diabo não teria o perdão, como nas narrativas anteriores (WATT, 1997, p. 40). 
Embora não tenha concluído a narrativa, Eça de Queirós deixou um "Plano da Obra", que segundo os editores ${ }^{6}$ foi "Encontrado juntamente com o manuscripto incompleto" (QUEIROZ, 1921, p. 261) e, no referido plano, não consta uma notável alteração do que, tradicionalmente, se relatou acerca de São Frei Gil. É possível cogitar, portanto, que o escritor não faria uma total desconstrução das antigas hagiografias, traçando outro final para o santo - como também não realizou nas outras lendas de São Cristóvão e Santo Onofre. O fato é que no "Plano da Obra", o autor deixa claro acerca da conversão e da devolução da cédula do pacto a Frei Gil, por intermédio da Virgem, e terminaria com a morte do frade "[...] em santidade" (QUEIROZ, 1921, p. 262).

Dado o entendimento sobre São Frei Gil, figurado em um dos relatos de Eça, passemos a averiguação da hagiografia queirosiana, se será possível assim denominar.

\section{A LENDA EGIDIANA SOB O LAVOR DE EÇA DE QUEIRÓS: UMA HAGIOGRAFIA NO SÉCULO XIX?}

Entendamos, primeiramente, a hagiografia tradicional. A narrativa da vida dos santos está ligada, segundo Roberto Gamberini, aos relatos dos feitos de personagens heroicas, que abundam na produção literária do Ocidente:

A par dos guerreiros e dos aventureiros, os novos heróis da era cristã são os santos. Às suas ações não bélicas, mas inegavelmente gloriosas, são dedicados numerosos poemas hagiográficos, alguns dos quais têm apenas a linguagem do epos [...], enquanto outros são considerados pela crítica moderna como épicos. (GAMBERINI, 2016, p. 495).

Isto é, com o advento do Cristianismo, sem abandonar os feitos das personagens heroicas que não foram vistas como modelos de santidade, os santos e as suas ações ditas gloriosas foram integrados à narrativa literária, sendo que alguns desses relatos passaram do status de simples relato ao de relato épico da vida de alguns modelos de santidade.

Aliás, a expressão modelo de santidade, que utilizamos aqui, revela, exatamente, o porquê, muitas vezes, se registrava a vida de um homem ou de uma mulher elevados ao grau da santidade. As hagiografias, portanto, têm origem longínqua, conforme propõe Pierluigi Licciardello:

\footnotetext{
A hagiografia da alta Idade Média é herdeira da hagiografia da Antiguidade tardia, cujos géneros principais prolonga: o martiriológio, a biografia (Passio ou Vita) e as resenhas de milagres. O martiriológio é uma forma de escrita da santidade, limitada aos poucos dados indispensáveis para identificar o santo no calendário litúrgico. (LICCIARDELLO, 2016, p. 542).
}

\footnotetext{
${ }^{6}$ A edição de Últimas páginas (QUEIROZ, 1921), que optamos utilizar neste estudo, foi publicada pela Livraria Chardron, de Lello \& Irmão. Traz sempre a informação dos editores, que acreditamos ter sido passada por Magalhães, o escritor que conheceu os manuscritos originais de Eça.
} 
A perseguição aos cristãos, imposta pelo Império Romano, resultou na origem de muitos santos mártires - aqueles que padeciam em nome da sua fé - e, com isso, o relato dos Martiriológios, que, grosso modo, como refere Licciardello, eram, praticamente, listas de informações básicas sobre o santo, para que se pudesse rememorá-lo ao longo do calendário festivo das celebrações da Igreja. Outra forma de cultivo destas narrativas, que remontam à Antiguidade, é a biografia ou vita, obviamente, compreendida diferentemente do que hoje entendemos pelos registros biográficos: as hagiografias relatavam os acontecimentos na vida dos santos, inclusive os que, atualmente, seriam considerados como maravilhosos e, na maioria das vezes, esses relatos deveriam ser propagados para a edificação da fé dos fiéis, pois os santos seriam modelos de santidade.

Como já averiguamos, Eça não é o único a reelaborar literariamente a vida de santos no contexto oitocentista. Em Portugal mesmo, há outros casos e, em França, por exemplo, Gustave Flaubert (1821-1880) revisitou a vida de Santo Antão (séculos III e IV) e publicou, em 1874, a narrativa La tentation de Saint Antoine, apresentando o anacoreta pai de todos os monges sob um olhar oitocentista.

E em Eça de Queirós, como se dá a narrativa da vida de São Frei Gil de Santarém? Há a preservação da hagiografia tradicional ou há uma revisitação com o olhar de um escritor do século XIX? Ora, obviamente, Eça não foi um simples repetidor dos antigos hagiógrafos, mas, como também verificamos, o autor não desconstruiu totalmente e, pelo "Plano da obra" que chegou até nós, provavelmente não pretendia uma reinvenção ficcional completamente contrária à que foi relatada pela tradição sobre a vida de Frei Gil. Contudo, é necessário que verifiquemos no texto de Eça como se dá a reelaboração da hagiografia.

Iniciemos pela concepção, pelo nascimento e infância do santo português na narrativa. O narrador, após dar as notícias sobre como viviam D. Ruy e D. Tereja, pais de Gil, assim relatam a gravidez:

Assim os annos tinham corrido, no solar de Gonfalim, quietos e eguaes, quando D. Tereja sentiu, alvoroçada, em si, um começo de maternidade. / Foi um pasmo, uma magnifica alegria. Longos annos elles tinham desejado, esperando com ardor, um filho; - e para obter D. Tereja fizera promessas, invocara todos os padroeiros da fecundidade, accendera durante trinta dias trinta velas a Santa Margarida, bebera agua de sagnacanina, trouxera muito tempo sobre a cinta uma pelle de coelha. Mas a doce esperança não se encarnava; [...] Todas as aias, tirando das arcas os linhos mais finos, trabalhavam no enxoval: - e D. Tereja, ao fim do primeiro mez, fôra commungar ao Mosteiro, para que a Hostia divina fôsse o primeiro alimento do menino bem-desejado. / De que cuidados cercava o bom Senhor aquella dona excellente, cujo ventre lhe parecia precioso como um sacrario! (QUEIROZ, 1921, p. 268-269).

Uma das características da gravidez de D. Tereja, descrita pelo narrador, remonta às histórias bíblicas: o desejo de se ter um filho e a dificuldade da fecundação. Isso se faz notável, a título de exemplificação, entre o patriarca Abraão e Sara, sua esposa (Gn 17, 19; 21, 1-8), Elqaná e Haná, pais do profeta Samuel (1Sm 1, 
5-20) e, no Novo Testamento, Isabel e Zacarias (Lc 1, 5-25), pais de João Batista. Nos casos bíblicos, a gravidez é vista como bênção e intervenção divina, chegando, em alguns casos, a ser preanunciada, antes da confirmação.

A narrativa queirosiana, por sua vez, dialoga com essa longínqua tradição do desejo, pelos pais, de uma gravidez, do sofrimento por ela não ocorrer e da concepção milagrosa. E, percebamos mais: Isaac - filho de Abraão e Sara -, Samuel - fruto da união de Haná e Elqaná - e João Batista, proveniente de Isabel e do sacerdote Zacarias são todos predestinados a um grande papel em seus espaços e tempos políticos e religiosos. Nos casos de Abraão, Sara, Zacarias e Isabel há ainda o agravante de os progenitores serem de idade avançada, contudo as suas crianças teriam grande proeminência na História Sacra. Certamente, é possível associar isso com a narrativa de Eça: o narrador, de certa forma, anuncia, ainda que de maneira velada, mas em consonância com as tradições pretéritas, que Gil seria um homem eminente. Observemos, ainda, que D. Ruy cerca D. Tereja de cuidados e, de acordo com o narrador, o ventre da mulher era como um sacrário, para o Senhor de Gonfalim. A comparação não nos parece descontextualizada com o restante da narrativa: o sacrário é um estojo ou arca em que se guardam o que há de mais sagrado dentro da tradição católica, a saber, as hóstias consagradas, que são, pela referida crença, o próprio Cristo feito pão. A voz narrativa de "São Frei Gil” já traça, ao relatar os cuidados paternos, uma relação da vida do santo português com o que há de mais sagrado.

Lopo (2013, p. 275), no entanto, propõe que “[...] Frei Gil atraiu diversos tipos de apropriação literária sendo paradigmático que, como alto dignitário eclesiásticopolítico que foi, seja muitos séculos depois apresentado como um paladino do progresso e da luta da ciência contra a superstição, em Eça de Queirós, por exemplo". Vejamos que, no trecho que transcrevemos, há menções a práticas de ordem religiosa e supersticiosa: D. Tereja, para conseguir engravidar, recorre a santos padroeiros da fecundidade. Ora, muitas dessas devoções tinham as suas origens no paganismo e foram, depois, substituídas por cultos a santos católicos. O narrador dá notícias de alguns ritos, como o acendimento de velas e o uso da pele de coelha numa nítida referência à fertilidade da fêmea - com a cinta - em torno do ventre. Até mesmo a relação com a pele do animal fecundo, algo bastante supersticioso, não é relatado de maneira pejorativa pela voz narrativa. O que nos parece, é que o relato corrobora a circunscrição histórica da lenda de São Frei Gil, muito embora esses ritos não estejam apenas limitados à Idade Média e perdurem em muitos lugares de Portugal, sendo, inclusive, trazidos para o Brasil, onde têm os seus desdobramentos e enriquecimentos culturais.

Ainda no mesmo trecho transcrito, há a referência de que D. Tereja comungou durante a gestação para que a hóstia fosse o primeiro alimento da criança. Observemos: as práticas de $\mathrm{D}$. Tereja não correspondem às normas oficiais do Catolicismo. Pelo contrário, são práticas, ainda que dentro da expressão católica, de uma religiosidade popular, mas não oficial. $O$ narrador não demonstra haver conflito entre essas práticas e outras, aí sim oficiais, como o batismo do bebê Gil. Elas 
convivem harmoniosamente nas ações do casal catolicamente piedoso: são, muitas vezes, as práticas do povo português, que são representadas sem depreciações nesta obra de Eça.

Ainda durante a gravidez de D. Tereja, alguns outros costumes e justificativas vem à baila, como o que segue:

[...] a ambos [D. Ruy e D. Tereja] vinha uma inquietação que não diziam - porque certas palavras, quando soltas, são apanhadas pelos Espiritos maus, que as condensam e d'ellas fazem causas reaes e vivas. Se Gil nascesse torto ou mudo?... Então D. Tereja ia escondidamente á capella fazer promessas á Senhora da Boa-Saude - e D. Ruy reclamava do Capellão que mais uma vez percorresse o tombo do seu solar, para vêr se jamais, varão da sua raça nascera com algum defeito. [...] e tendo uma manhã avistado uma gralha que pousara no rebordo do seu aposento, o que poderia tornar o menino gago - de tanta angustia se tomou, que [...] jazeu uma semana no seu vasto leito, entregue ás drogas do Mestre Alvaro Porcalho, o bom Physico que viera à pressa de Vizeu, montado na sua mula. Por conselho d'elle, D. Tereja nunca mais tocou agua fria, e só bebeu caldos de cobra. (QUEIROZ, 1921, p. 269-270).

Mais uma vez, os detalhados relatos das superstições estão muito mais colaborando com a circunscrição medieval da narrativa - e não estamos afirmando que a Idade Média foi um período apenas de superstições - contudo, a justificativa de diversos acontecimentos via explicações sobrenaturais fez parte do quotidiano do medievo. Um exemplo disso é a exótica recomendação de Porcalho para D. Tereja tomar os caldos de cobra, algo embasado na tradição popular portuguesa, pois, de acordo com Moisés Espírito Santo (1984, p. 47), "Ao caldo de cobra atribui-se o poder de facilitar os partos". É possível observar, portanto, que o próprio D. Ruy faz uso dos recursos que lhe estavam ao alcance naquele período, chamando um físico de Viseu e não apelando apenas para o sobrenatural: por isso há muito mais relação com a delimitação histórica da narrativa do que com críticas ferrenhas às superstições. Francesco Stella pode nos auxiliar a compreender melhor a definição espaço-temporal de "São Frei Gill" com as suas assertivas:

[...] na Idade Média, qualquer fenómeno pode e deve ser explicado como sinal do divino; até um monstro, um animal inexistente, a fala de um morto ou o rosto de um demónio, tudo está inserido numa ordem que se apresenta coerente e compacta, e nesta ordem qualquer forma visível tem sentido em si própria e é portadora de um sentido ulterior, de uma mensagem para as outras. (STELLA, 2016, p. 511).

O pouso da gralha na orla da janela do aposento, referido pelo narrador, e que faz adoecer D. Ruy, temente de que Gil nascesse gago, é explicado pelas proposições de Stella. A voz narrativa está, portanto, reforçando a circunscrição da temporalidade da história de Frei Gil: a presença daquela ave no parapeito do aposento era sinal de maus auspícios. Não nos parece tanto uma crítica, nestes casos, mas uma composição 
narrativa muito preocupada em descrever um período longínquo do momento da escrita, o século XIX. Aliás, o início de "São Frei Gil" se assemelha demasiado às descrições e delimitações abundantemente cultivadas nos romances históricos, como as produções de Alexandre Herculano (1810-1877) ou Almeida Garrett:

O solar de D. Ruy de Valladares, Senhor de Mortagua e Gonfalim, era a duas leguas duras de Vouzella, n'uma collina, por onde descia, espalhada até o rio, entre olivaes e vinhedos, a aldeia de Gonfalim. Um fosso, uma muralha delgada e simples como um muro d'herdade, uma torre construida em tempos da Senhora Rainha D. Tereja, defendiam a casa terrea, a capella, os celleiros, o forno, o pateo bem lageado, onde dois chorões davam frescura e sombra a uma fonte de bronze. [...] / No fundo do valle [...]: um mosteiro rico de Dominicos occupava toda a collina fronteira de Gonfalim, com a sua vasta, frondosa cerca: - e as duas margens eram ligadas por uma velha ponte romana d'um só arco, onde o bom Senhor, para purificar a obra e a pedra pagã, mandara erguer um cruzeiro. (QUEIROZ, 1921, p. 263-264).

Percebamos que a narrativa de "São Frei Gil" se inicia com as descrições do solar de D. Ruy e das suas imediações. Há uma clara circunscrição espacial, com descrições dos muros de proteção - nítida referência às fortalezas medievais - e também da natureza que circunda o lugar - sobre o que também abordaremos neste trabalho. Semelhante a um romance histórico tradicional, algumas notícias acerca da época em que a história se passa estão em detalhes referidos pelo narrador: D. Ruy manda erigir um cruzeiro a fim de "cristianizar" uma ponte, obra que remonta aos tempos da dominação de romana na Península Ibérica, entre os séculos III a.C. e V da Era Cristã. Ora, tal ato não seria comum no período oitocentista, mas desvela o espírito de uma época pretérita, inclusive pela crença de que "A cruz é o símbolo mais poderoso, que une e separa ao mesmo tempo, e evoca tanto a vida como a morte" (ESPÍRITO SANTO, 1984, p. 47). Vejamos, contudo, que novamente a voz narrativa de "São Frei Gil" não tece comentários irônicos sobre a construção de um cruzeiro e nem usa termos pejorativos: dá-nos a informação de que assim o foi e, consequentemente, nos situa no espaço e tempo em que a narrativa está ambientada.

Outros costumes, descritos ao longo do enredo, corroboram a circunscrição medieval da história do santo, como a vinda de um astrólogo, Mestre Leonardo, ainda durante a gestação de D. Tereja, para preparar o horóscopo do menino. Era, de fato, costumeiro que os reis e nobres, antes de batalhas ou de tomarem decisões importantes, consultassem os astrólogos e, até mesmo os papas, os mantinham em suas cortes. A profecia de Mestre Leonardo acerca do menino Gil, contudo, cumprese em partes, pois o astrólogo previu que o "[...] filho seria varão, venceria os infieis, entraria nos Conselhos d'El-Rey, e desposaria a filha d'um Rico-Homem poderoso, que tinha tres castellos, e vassalagem de tres villas" (QUEIROZ, 1921, p. 270-271). Ou seja, de fato, nasceu um menino e a sua vida seria, após a conversão, de vitória contra os infiéis, talvez não da maneira como se imaginaria: não pela espada contra os muçulmanos, que sob a ótica cristã eram os infiéis, porém, pela vida religiosa e douta, venceria as tentações e o mal. Sobre a participação política no Conselho Real, há a 
hipótese de que, historicamente, Frei Gil tenha uma participação política muito importante, "[...] como representante do Papa no complexo processo de retirada de confiança e subsequente deposição de D. Sancho II (pela bula Grandi non immerito de Inocêncio IV, de 1244 [...]) e a sua substituição por Afonso III” (LOPO, 2013, p. $272)^{7}$, mas, como sabemos, o santo não chegou a se casar com uma das filhas dos grandes nomes da nobreza. Talvez não tanto em sentido de crítica às superstições, o narrador nos comunique a realização parcial dos prenúncios do astrólogo: é possível que seja apenas um relato para a delimitação temporal da narrativa. E, na época em que "São Frei Gil" está ambientada se recorriam a muitos desses métodos adivinhatórios, que não são exclusividade do período. Além disso, a descrição dada no enredo da narrativa reforça os múltiplos cuidados que os pais do menino Gil tiveram antes mesmo do nascimento do santo: ademais das comuns preocupações paternas, está, ainda que implicitamente, a informação sobre a importância do menino, que foi zelosamente esperado, gestado e predito.

Como verificamos, "São Frei Gil" é uma narrativa produzida posteriormente aos mais conhecidos romances de Eça de Queirós. Antonio Candido, no ensaio "Entre campo e cidade", que foi originalmente composto para o centenário do autor, considera que com a publicação de Os Maias, em 1888, exprime um paulatino recuo ideológico do escritor, pois

[...] Eça já não era o romancista urbanófilo das primeiras obras, também já não era mais o socialista dos primeiros tempos: havia abandonado a linha da oposição e do sarcasmo integral. [...] começa a deixar-se invadir pela sedução do velho Portugal. Os seus romances irão revelando, pouco a pouco, um abandono do ponto de vista urbanista em proveito do sentimento rural; em proveito daquele mesmo passado de que êle a princípio renegou integralmente. (CANDIDO, 1964, p. 41).

É fato que, como estamos demonstrando em “São Frei Gil”, por exemplo, há uma pormenorização de tradições populares - num nível de circunscrição da narrativa - sem os sarcasmos que encontramos em outras obras ecianas. Entretanto, também é preciso averiguar, com base nos estudos desta narrativa, se podemos realmente afirmar que Eça passou a estar "[...] reconciliado com o sentido tradicional da civilização da sua pátria” (CANDIDO, 1964, p. 45). Voltemos, para tanto, à narrativa dos ritos, aos quais a criança foi submetida:

\footnotetext{
7 José Mattoso (1999, p. 126-131) refere as grandes confusões causadas entre alguns bispos, o clero secular e as Ordens Mendicantes - Franciscanos, sobretudo, e Dominicanos - durante o reinado de D. Sancho II (1209-1248) e discorre que "Em 24 de Julho, depois de encerrado o Concílio de Lião (17 de Julho), onde tinha excomungado Frederico II, [...] [o Papa Inocêncio IV (1195-1254)] emitiu a bula de deposição de D. Sancho II (Grandi non immerito) dirigida aos barões, concelhos e povos de Portugal, bispos e clero, Franciscanos e Dominicanos e principalmente às quatro ordens militares. [...] Sancho II não perdia a coroa, mas era declarado incapaz de governar, como rex inutilis. Afonso de Bolonha não era nomeado rei, mas apenas governador e defensor do reino em vez de seu irmão" (MATTOSO, 1999, p. 131).
} 
Para que elle tivesse uma voz forte e bella, [D. Ruy] esfregava-lhe a boquinha com uma velha moeda d'ouro. Elle mesmo desfizera sal virgem em agua tirada da fonte ao nascer do sol, que faz com que o cabello das creanças nasça encaracolado e basto. Para que elle tivesse força, trouxe uma antiga espada do seu avô D. Frulas, e pousou-a entre as mãosinhas de Gil: - e para que, á força do corpo, se juntasse a força da alma, tres domingos a seguir o Capellão veiu lêr sobre o berço o Evangelho dos tres Reis. (QUEIROZ. 1921, p. 273).

São múltiplos os exemplos de ritos populares descritos no trecho supratranscrito. Obviamente, entre os círculos intelectuais do século XIX, esses credos não eram vistos como exitosos, pois uma moeda ou a água recolhida pela manhã não poderiam cientificamente influenciar na voz ou nos cabelos de um indivíduo. Porém, entre as massas, num país de grande herança religiosa, ainda eram entendidos como ritos de grande eficiência, já que "A eficácia de que gozam estes ritos, ou estas técnicas, não resultam nem das palavras nem dos produtos utilizados, mas sim da “intenção"' (ESPÍRITO SANTO, 1984, p. 147).

Vejamos que, na narrativa de Eça, há inclusive a participação do padre capelão em um rito não prescrito oficialmente pela Igreja: a recitação do Evangelho dos Magos (Mt 2,1-12) por três domingos seguidos junto ao berço do pequeno Gil, a fim de que a criança adquirisse forças. Isso demonstra o quanto a religiosidade popular (simbolizada por um rito extra-formal) se entranhava com a religiosidade oficial (representada pela participação do representante da Igreja, o capelão). A voz narrativa, contudo, não faz menções irônicas ou críticas a essas fórmulas populares: limita-se a relatá-las, o que, novamente, corrobora a nossa ideia de que há nessas descrições a tentativa de circunscrição do espaço e do tempo. Para pensarmos, sobretudo na última fórmula referida pelo narrador, é possível recorrer às proposições de Espírito Santo:

Para designar o acto de dirigir-se a uma divindade, a linguagem popular utiliza a palavra rezar que, etimologicamente, significa recitar, dizer uma fórmula [...]. Por outro lado, a religião popular ignora os louvores gratuitos, desprovidos de um fim interessado. É que todas as boas relações são construídas na base do "toma lá, dá cá" (ESPÍRITO SANTO, 1984, p. 145, grifo do autor).

A experiência relatada pelo autor fica patente em "São Frei Gil": nenhum dos ritos é gratuito, todos têm um porquê, mesmo a fórmula de recitação do Evangelho junto ao berço do pequeno santo. E o narrador afirma que o capelão reforçou por três vezes o ato, ao que, ao explicar algumas dessas fórmulas, Espírito Santo (1984, p. 147) afirma que "A repetitividade é também uma condição importante, [...] as fórmulas prescrevem geralmente o número três ou os seus múltiplos".

$\mathrm{E}$ as descrições rituais prosseguem na reelaboração da história de Frei Gil: 
Pelo baptisado foram celebradas grandes festas. O padrinho foi $\mathrm{D}$. Mendo, um parente de Mortagua - a madrinha Nossa Senhora da Saude: e no caminho para a Egreja, juncado de rosas e herva-doce, ao lado de D. Mendo, magnifico, [...] caminhava, no seu andor, aos hombros de quatro cavalleiros peões de Gonfalim, a Senhora Madrinha, coroada de ouro, com um manto novo, onde as estrellas d'ouro, sobre o azul do velludo, faziam como um céu de verão. Para maior honra (e para que o menino não fôsse surdo), foi D. Mendo, o padrinho, que puxou a corda do sino, deu os primeiros repiques festivos. Toda a pedra da Egreja desapparecia sob as colgaduras de velludo branco. E quando a ponta d'uma faixa de seda que se prendia, pela outra ponta, ás mãos da Senhora, veiu tocar a pennugem fina e loura da cabeça de Gil, nusinho e quieto, nos braços do Padre, sobre a Pia - todos observavam com espanto, que o menino sorria às luzes das tochas [...] e alguma cousa de branco, como o sulco d'uma aza, passou na penumbra do Baptisterio. (QUEIROZ, 1921, p. 273-274).

O rito batismal de São Frei Gil é assinalado, na narrativa eciana, por várias fórmulas significativas: a começar pelo sorriso da criança ou pela cor branca, da qual se revestiu a igreja, uma cor muito própria para estas ocasiões, pois evoca a purificação do pecado original. Mas, igualmente, pela escolha dos padrinhos, por exemplo, em que figuram D. Mendo e Nossa Senhora da Saúde. Não é qualquer invocação da Virgem, senão uma que remonta à sanidade para a criança. Nesse gesto, mais uma vez não referido de maneira depreciativa pelo narrador, podemos vislumbrar a intimidade com a santa, que não perdeu a sacralidade dentro da economia da narrativa ou na lógica dos pais de Gil, porém passa a ser um membro da família, isto é, a madrinha do menino. Na história oficial de São Frei Gil, é a Virgem Maria que resgata a cédula na qual o santo havia firmado o pacto com o Demônio (LOPO, 2013, p. 270), atuando, de fato, como uma "madrinha".

A imagem da Virgem da Saúde, antes do rito batismal, acompanha a família e o padrinho até o templo: a imagem é honrada com flores e ervas perfumadas, porta um manto e uma coroa e é carregada em um andor por quatro cavaleiros. Ou seja, forma-se uma procissão, um rito deambulatório até a igreja local, que soleniza ainda mais o dia, pois se transpõe para além do templo. O repicar festivo do sino, pelas mãos de D. Mendo, para honrar o padrinho e também para evitar a surdez da criança pode ser entendido por meio da proposição de Espírito Santo (1984, p. 89), quando explica o significado dos sinos para a religiosidade popular: "O seu repicar é altamente mobilizador [...] a respectiva voz [do sino] afasta toda a espécie de perigos, desde os espíritos, as bruxas ou as larvas do milho, à tempestade, às epidemias".

A fita de seda, que pende das mãos da imagem da Virgem da Saúde e toca a cabeça do pequeno Gil, estabelece entre ambos o elo do apadrinhamento: dessa forma é como se as mãos da Senhora, representada pela estátua, estivesse tocando a cabeça do menino santo. Para, contudo, coroar o momento do batismo, há uma manifestação milagrosa: uma espécie de asa passa pelo batistério, estabelecendo uma relação, ainda que rápida, com o relato evangélico da manifestação que se dá após o batismo de Jesus, no rio Jordão, quando, em forma de pomba, o Espírito se manifestara (Mt 3,16-17). 
Os milagres abundam, na narrativa de Eça, sobretudo, na infância de Gil. Desde o nascimento de seus dentes, um processo naturalmente custoso e dolorido, mas que "[...] lhe vieram, sãos e faceis, sem lhe custar uma lagrima" (QUEIROZ, 1921, p. 275). E o narrador prossegue nos dando as seguintes informações:

No aposento, onde estava o seu berço, não era necessario no inverno aquecer o brazeiro, nem, nas caniculas, entreabrir as janellas á aragem - porque havia alli sempre um ar egual, doce, tepido, fresco, e que cheirava bem: - mesmo este aroma ia crescendo, e tanto, sobretudo em volta do seu berço, que o mestre Porcalho, que reprovava as essencias derramadas junto dos berços, [...] dizia, franzindo a venta: "Mas aqui cheira a jasmim! Mas aqui cheira a rosa!'. Mais d'uma vez tambem succedera que apagando-se a lampada, o quarto continuara allumiado, d'uma luz translucida, vaga, lactea, [...] como irradiada, em torno do berço (QUEIROZ, 1921, p. 275-276).

O narrador relata com naturalidade esses acontecimentos maravilhosos: o aroma do quarto do menino e a luz que envolve o berço da criança. Pierluigi Licciardello discorre que

O milagre, sinal prodigioso da santidade, invade a hagiografia. Os milagres são registados e circulam de uma forma autónoma. O milagre é a reparação da ordem natural das coisas, ordem transtornada pelo homem pelo pecado, ou pelo próprio demónio, que o santo restaura usando a sua capacidade de mediação entre o terreno e o divino. O santo é cada vez mais intercessor, mediador do sagrado, uma pessoa dotada de poderes sobrenaturais para usar em defesa dos fiéis que se confiem à sua proteção. (LICCIARDELLO, 2016, p. 543).

Ora, obviamente Eça de Queirós não elaborou uma hagiografia tradicional, pois reelaborou muitos detalhes e acrescentou outros elementos nas lacunas da história do frade Gil. Contudo, é notório que o autor se valeu de algumas técnicas próprias dos antigos relatos de santos, como a pormenorização dos milagres, que reforçam, novamente, a circunscrição histórica, temporal e espacial da narrativa, mas, igualmente, robustecem a imagem da santidade de Gil, já que desde a infância as manifestações maravilhosas o envolviam, como um escolhido:

As pombas, que tinham o seu pombal na velha torre d'atalaya, começaram então a vir todas as manhãs, em bando, pousar sobre o rebordo da janella do menino: - e mesmo, se encontravam as portas abertas, algumas mais ousadas, por serem mais brancas, voavam em torno do seu berço, d'um vôo subtil e sem rumor. [...] e se [Gil] tocava em alguma que pousasse nas grades do berço, essa tomava logo o vôo, triumphante, mergulhava muito alto no azul, e não recolhia ao pombal. / Mas não eram só as pombas que amavam o menino. Borboletas raras, de côres radiantes, vinham bater contra os vidros, aos bandos, como folhas vivas [...]. Uma amendoeira que havia em baixo, no pateo, rompeu a crescer, a subir, como se as pontas das suas ramagens tentasse espreitar para dentro do aposento: - e depois cobriu-se de flôres em janeiro; e 
um rouxinol veiu durante todo o inverno cantar sobre ella maravilhosamente. Mas a surpresa maior foi que no canto do pateo lageado, onde se despejara a agua em que D. Gil tomara banho, começaram a crescer por entre as lages umas florinhas azues, brancas e côr d'ouro, que nenhum jardineiro jámais vira, e que perfumavam todo o ar. / [...] Frei Munio murmurou: "N’este menino há maravilha!" (QUEIROZ, 1921, p. 276277).

$\mathrm{Na}$ narrativa queirosiana, a própria natureza reconhece que há algo extraordinário no menino Gil. As pombas, que não deixam de ser uma maneira imagética de manifestação da terceira pessoa da Trindade, sobretudo as de maior alvura, pousam sobre o berço da criança. As borboletas mais coloridas acorrem à janela do aposento do santo e um rouxinol canta próximo nas ramagens em plena estação mais fria. Também a árvore cresce miraculosamente e aflora no inverno europeu, como é próprio da amendoeira, uma das primeiras plantas a florescer antes mesmo da primavera: reforçamos que a árvore, na narrativa de Eça, é uma amendoeira, cujo significado bíblico é muito corrente. No livro do Gênesis (43, 11), por exemplo, o patriarca Jacob envia ao Faraó presentes e, dentre eles, as amêndoas. No Êxodo (25, 31-38), Deus fala a Moisés para que faça um candelabro - a menorá judaica - de ouro, em que, como ramos, saíssem de uma haste central e os aparadores das lâmpadas tivessem forma de amêndoas com botão e flor. No livro dos Números $(17,23)$, Deus escolhe Araão pelo bastão que desabrocha em flor e fruto de amêndoa. O profeta Jeremias (Jr 1, 11-12) tem a visão de um ramo de amendoeira, significando a vigilância de Deus sobre o seu povo - e, também pela floração prematura, a amendoeira significa o ato da vigília e atenção - e, de forma parecida, figura no Eclesiastes (12, 5), como alerta para a brevidade da vida humana. A iconografia e a arte arquitetônica cristãs, tributárias de outras tradições, representaram, muitas vezes, a sacralidade por um halo, comumente representado na forma oval - do italiano, a mandorla - em forma de amêndoa, muito utilizado na arte bizantina e românica, que envolve todo o corpo de algumas representações iconográficas de Cristo ou da Virgem, representando a glória ou a majestade. Certamente, não está a árvore figurada ao acaso em "São Frei Gil": é, primeiramente, o relato de um crescimento e florada miraculosos, mas estão em íntima relação com os textos bíblicos e com as figurações artísticas.

O surgimento das flores desconhecidas no pátio lajeado, onde se despejava a água do banho do menino Gil, é outro fenômeno miraculoso da narrativa eciana e envolve a manifestação da natureza em reconhecimento da santidade do menino, expressada diretamente por Frei Munio. Candido $(1964,46)$ propõe que a obra de Eça de Queirós passava por uma “[...] integração na convenção bucólica e a busca de um sentido mais harmonioso na existência campestre" e prossegue, afirmando que

As vidas dos santos, principalmente a de São Cristóvão, importam pelo mesmo motivo. Nota-se, aliás, que em Eça de Queirós o ruralismo e mesmo o tradicionalismo vieram corresponder a tendências literárias acentuadas, quais sejam o sentimento plástico e o talento descritivo. O campo sempre foi oportunidade para algumas das suas melhores 
descrições e ambientes mais sugestivos. [...] Os seus livros precisam respirar, e não sossegam enquanto não encontram uma nesga de natureza (CANDIDO, 1964, p. 4647).

A interpretação crítica de Candido, que teve a sua importância histórica, ainda hoje ressoa na exegese dos textos de Eça de Queirós, sobretudo os do fim de sua vida, como é o caso da narrativa que escolhemos para análise neste estudo. E, embora, de fato, as descrições ligadas à natureza são realizadas com maestria na obra querosiana, é embaraçoso afirmar que as vidas de santos correspondem a ideais ruralistas e tradicionalistas, porque "Eça jamais se libertou da velha moral portuguêsa, do culto idealizado da honradez aldeã e forte" (CANDIDO, 1964, p. 49). O que estamos verificando, especificamente em "São Frei Gil", é que o autor também se valeu de estratégias narrativas próprias das hagiografias tradicionais, sem satirizar os costumes populares. Mas, isso não significa que o relato aponte para um tradicionalismo, simplesmente porque tem como protagonista um santo português, até porque há também outras questões que são acentuadas na caracterização de Gil.

O mesmo santo menino, de desenvolvimento maravilhoso, que, quando ainda criança,

[...] na egreja, de joelhos sobre a almofada, no altar-mór, com as mãos postas, [...] tanto se penetrava da pobreza e dôr por que Jesus passara, vendo o seu corpo nú e pequenino nas palhas do curral, a sua tunica rasgada pelos açoites, varadas pelos pregos, que os olhos se lhe enchiam de lagrimas. (QUEIROZ, 1921, p. 280)

Esse mesmo menino que se compadece dos sofrimentos de Cristo, será a criança que quase definhará de tanto estudar (QUEIROZ, 1921, p. 285), porque "De noite, com o candil pendurado junto do leito, e um folio no travesseiro, lia ainda, lia tanto" (QUEIROZ, 1921, p. 284). Depois, com o seu desenvolvimento, Gil passará por vários anseios de aprendizagem, que não apenas o dos livros: o desejo de ser cavaleiro (QUEIROZ, 1921, p. 302-303) e as aspirações às ciências médicas (QUEIROZ, 1921, p. 306-307). O que pode nos soar como algo bastante natural para as descobertas e as pretensões de um adolescente, Sofia de Sousa Silva vislumbra a vivência do conflito da insaciabilidade e o compara com a personagem de outro romance eciano, $A$ cidade e as serras, publicado postumamente, em 1901:

Em muitos aspectos, Gil é um Jacinto de outra época. Sua vida não poderia ser mais doce, tudo que desejava lhe era dado pelas mãos de Deus, dos pais ou do Diabo. Segundo o plano da obra deixado por Eça de Queirós, Gil se tornaria sucessivamente rei, pirata, estudante, até finalmente abraçar a vida religiosa. Em última análise, é a saciedade e a experiência, ou talvez o tédio de quem já experimentou de tudo que o fará voltar-se para o próximo e dedicar-se à religião. São frei Gil, como Jacinto, é um dândi, mas que encontra na vida religiosa o sentido da sua existência, a grande resposta à sua inquietação permanente que o fazia assumir diversas funções. (SILVA, 2002, p. 250) 
A personagem Jacinto, a qual refere Silva, vive uma tensão no romance: o conforto de Paris, a vida agitada da grande cidade, a vida requintada de dândi, as muitas atividades que uma metrópole propicia e a rica e imensa biblioteca não preenchem o vazio da protagonista, que encontra uma vida mais amena ao se retirar para a quinta em Tormes, no Baixo Douro de Portugal, porém levando boa parte do conforto de sua moradia parisiense. O paralelo entre Jacinto e São Frei Gil, enquanto personagens ecianas, é possível, ainda que os movimento das personagens na economia das narrativas sejam um tanto distinto: Jacinto habita o palácio n. ${ }^{\circ}$ 202, nos Campos Elísios, em Paris $^{8}$ e descobre a alegria do sol, da culinária e da vida sem grandes agitações em Tormes, enquanto que Gil habita Gonfalim, porém sente-se desejoso de ir para além, descobrir o que há para fora das terras de seus pais:

Um dia, [...] levado pelos seus pensamentos, foi dar ao alto d'uma collina, que era a mais alta n'aquelles sítios, e se chamava a serra do Bruxo. D'alli via, mais baixas, a vasta collina onde negrejava o seu solar, a aldeia de Gonfalim, espalhada entre a verdura, o branco Convento dos Benedictinos, o rio luzindo entre as margens [...] e de pé, [...] Gil começou a considerar quanto era estreito aquelle horizonte, e quanto seria impossivel, na verdade, que dentro d'elle se realisassem sonhos que abrangiam o mundo todo. Que havia alli, n'aquelle circulo de collinas? Os muros de seu solar, um convento de velhos frades, uma aldeia de pobres colonos, e para além, terras bravias, mattos, collinas [...]. Como poderia jámais ser alli o homem que desejava, o homem de grande saber, de grande acção? [...] Mas para além havia outras terras, grandes reinos, cidades ricas, grandes escolas, mosteiros de alto saber, as multidões innumeraveis, sobre quem uma alma forte e bem provida podia exercer uma supremacia que valesse a pena conquistar. Se elle deixasse o seu lar estreito! se elle partisse! (QUEIROZ, 1921, p. 314-315).

É nítido que Eça bebe da fonte dos modelos hagiográficos tradicionais, com um narrador que se demora na descrição dos milagres e maravilhas do santo, mas vai além. A voz narrativa de "São Frei Gil", em discurso indireto-livre, ou seja, revelando os pensamentos mais íntimos do santo, dá-nos notícias das tensões individuais do jovem de Gonfalim: ficar ou partir, como se dissesse que há muita vida para além da aldeia portuguesa. Em suma: o enredo de "São Frei Gil" está circunscrito ao medievo e o narrador, como vimos, faz diversas menções a isso, a fim de construir uma ambientação mais próxima do período -, porém o conflito individual do santo é extremamente moderno, pois há a tensão com a insatisfação. Neste caso, Eça de Queirós não compôs uma hagiografia para a edificação de fiéis, mas sim uma narrativa que discute a angústia e a inquietação do ser humano na sociedade moderna. É, portanto,

\footnotetext{
${ }^{8}$ Já no primeiro capítulo de A cidade e as serras, com a voz narrativa da personagem José Fernandes, temos as seguintes informações: "O meu amigo Jacinto, nasceu num palácio [...]. A sua quinta e casa senhorial de Tormes, no Baixo Douro, cobriam uma serra. [...] Mas o palácio onde Jacinto nascera, e onde sempre habitara, era em Paris, nos Campos Elísios, n. ${ }^{\circ}$ 202" (QUEIROZ, 1945, p. 5).
} 
uma recriação de um mito nacional de origem medieval, para refletir, inclusive, sobre as preocupações individuais - não mais míticas - na modernidade.

Silva (2002, p. 250) refere que no "Plano da obra" deixado pelo escritor, há menções que ficaram por elaborar, de que o Diabo, após o pacto, daria a Gil diversas funções e bens. De fato, isso se faz presente e atentemos para como está relatado:

Começa pela vida de moço, tendo palacios, mulheres, ouro ás pilhas. - Mas depressa se cança disto. / Ambiciona então o poder, e o Demonio fal-o Rei. - Mas depressa se cança da realeza. / Appetece então as grandes aventura, e é pirata nos mares até os ultimos sertões, vê povos extranhos. - Mas depressa se cança d'estas emoções. / Então appetece tudo saber, e vae estudar para Paris, como simples estudante. - Mas depressa se cança d'esta sciencia dos livros./ Quer saber os mysterios. - O diabo leva-o aos astros, penetram nas entranhas da terra. (QUEIROZ, 1921, p. 262).

Como podemos verificar, há na narrativa queirosiana uma mescla entre elementos fantásticos, como a presença do Diabo e a feitura de um pacto, com a reflexão acerca das angústias e dos desejos humanos: nada satisfaz, no "Plano da obra", a protagonista, pois deseja sempre mais, quer sempre mais e se cansa facilmente das aventuras, do poder e do saber. Dada a complexidade desse texto, ainda que inacabado, é difícil afirmar que Eça de Queirós foi “[...] pondo de lado o sentido pragmático, de luta, dos primeiros livros" (CANDIDO, 1964, p. 53), como propõe Candido, já que as narrativas do fim da vida do escritor, e aqui especificamente "São Frei Gil", não deixaram de refletir criticamente sobre a sociedade. É possível verificar, neste caso, uma menor acidez da voz narrativa, mas sem deixar de lado a criticidade. O retrato de São Frei Gil, na narrativa eciana, não deixa de ser pragmático, para utilizarmos a expressão de que se valeu Candido, pois está abundantemente referenciado em realidades sociais, como a insaciabilidade humana e o tédio após alcançar algo que tanto se deseja.

Candido sinaliza, ainda, um possível conformismo - esse é o termo utilizado pelo crítico - com a realidade portuguesa e também um acomodamento nas produções derradeiras do autor:

[...] era de se esperar que o seu socialismo [de Eça] e a sua irreverência acabassem por ser, não vencidos, que nunca o foram, mas equilibrados, compensados, pela irrupção dos antigos valôres recalcados: sentido rural da vida; acatamento da tradição; conformismo em relação aos podêres estabelecidos; senso poético, em vez de destruidor, da cultura portuguêsa. / [...] ao mesmo tempo que a própria idade o ia tornando mais acomodado e compreensivo. (CANDIDO, 1964, p. 50;52, grifos nossos)

As justificativas de Candido, próprias também do período de escrita de seu ensaio crítico, são embasadas na biografia do autor português, incluindo o seu suposto amadurecimento etário. Obviamente, é possível estabelecer relações entre a vida de um escritor e as suas produções literárias, porém, parece que o crítico está 
reforçando apenas uma interpretação quase psicológica das produções e do próprio Eça de Queirós - vejamos as expressões irrup̧̧ão e recalcados: como se algo, existente, fosse reprimido durante toda a primeira produção ficcional do autor e depois, como num rompimento de um dique, visse à tona em grande explosão. Candido, no trecho supramencionado, reconhece que Eça nunca teria perdido a sua irreverência - e passaremos a analisar se isso é observável em "São Frei Gil" - contudo, propõe que o escritor passou a acatar as tradições e se conformar com os poderes estabelecidos. $\mathrm{O}$ embasamento argumentativo de Candido se dá porque Eça “[...] escreveu as vidas dos santos, e levou o requintado Jacinto ao repouso idílico da serra de Tormes" (CANDIDO, 1964, p. 53). O romance $A$ cidade e as serras merece uma análise própria e pormenorizada, que não temos como, por óbvios motivos, realizar neste estudo, exatamente porque não é algo tão simples: há uma grande complexidade figurada em Jacinto e na trama narrada por José Fernandes. E o que devemos deixar muito claro aqui é que, não é porque Eça se dedicou a escrever vidas de santos, que o autor tenha se tornado um "[...] apenas resignado" (CANDIDO, 1964, p. 53) ou conformado ou, ainda, embora não seja esta a ideia de Candido, um reacionário. A retomada das tradições portuguesas, como já exploramos, se dá em "São Frei Gil” e também as pormenorizações de ambientes naturais, todavia há essa apropriação para a elaboração da própria narrativa, que, conforme já mencionamos, aponta para a reflexão sobre um tema muito mais denso: as múltiplas ofertas realizadas ao homem moderno e o tédio, ao mesmo tempo, que isso pode gerar. As tradições e os pormenores da natureza têm os seus fundamentos tanto internos quanto externos à narrativa - como as relações com as fontes bíblicas, por exemplo - e é inegável que são ricamente elaboradas e revisitadas, mas elas são muito mais parte da circunscrição da narrativa querosiana.

Vejamos, entretanto, o episódio do adoecimento do D. Abade, do Mosteiro junto às terras de D. Ruy, e dos conselhos que o religioso destina ao nobre acerca do menino Gil:

D. Ruy lamentou o bom Abbade, - e, sentado n'um escanho aos pés do leito, contou logo como justamente o seu Gil começara agora com o grande desejo de saber a arte de curar aquelle e outros males. - Pois mandae-o estudar a França!... - accudiu logo o D. Abbade, estendendo a mão fóra da roupa, com um gemido. - Não sei que haja mais util saber. Mas nós, aqui n’este Reino, nem uma dôr sabemos calmar... Não o digo pelos doutos padres d'esta casa!... Mas já desde Domingo, que foi a merenda, estou aqui em trabalhos... Estamos em grande atraso... Mandae-o estudar a França. / E, pregando os olhos nas santas Reliquias, ficou mudo. / Só quando D. Ruy lhe beijou o annel da mão, cahida sobre a colcha de seda, tornou a voltar o rosto, a murmurar: - Mandae-o estudar a França. (QUEIROZ, 1921, p. 309)

Seria o trecho transcrito um resvalo na escrita de Eça não conformado? É, obviamente, melindroso afirmar que o discurso de uma personagem reflete o pensamento do escritor, todavia é possível verificar como, nem tudo, em "São Frei Gil” são elogios pátrios ou resignação: permanece o discurso crítico do atraso 
português - transposto para ainda o reino medieval - e do elogio a França, como espaço dos saberes, sendo colocado na boca de um Abade, que, embora afirme não desprezar os doutos saberes do mosteiro, recomenda que Gil vá para o estrangeiro a fim de estudar. Percebamos, que neste excerto, há menções às sagradas relíquias, pois "[...] as Reliquias do convento estavam expostas, sobre um pequeno altar, para dar saude ao bom Abbade" (QUEIROZ, 1921, p. 308), enquanto que "Um frade rezava junto ao vasto leito de carvalho. Outro pisava uma massa dentro d'um almofariz - e dois noviços, com ramos de louro, sacudiam as moscas da face veneravel [do abade]" (QUEIROZ, 1921, p. 308-309). Nesse caso, novamente temos informações que nos servem para a circunscrição da narrativa no medievo: um frade amassando algo num pilão, o que de ser um fármaco para atender o superior, enquanto que as relíquias estão expostas, como representação da crença mágica de que tinham poder curativo. Entretanto, quando conjugamos o discurso do abade com as descrições de como estavam dispostas as coisas em sua cela, percebemos que é possível afirmar a existência de uma situação alegórica: a doença do abade, que não era algo tão grave, pois se tratava de um desarranjo intestinal, a não resolução do problema e a crença no poder curativo das relíquias, como algo mágico e supersticioso, revelam o Portugal atrasado, tantas vezes denunciado por Eça de Queirós. A cena está sim circunscrita, na narrativa, em outro período histórico - e reforçamos que ela auxilia nessa construção da ambiência - mas, se formos além do tempo histórico da narrativa, é factível percebermos a crítica, ainda que de maneira discreta.

Para pensarmos ainda mais sobre o texto "São Frei Gil", tomemos as afirmações de Silva, em que ressoam a ideia de que Eça, com efeito, havia acatado a ordem dominante e estaria resignado:

À primeira vista, as histórias de Cristóvão, Onofre e Gil guardam pouca relação com o restante da obra de Eça de Queirós. Salta aos olhos o fato de que o narrador das lendas de santos é inteiramente diferente dos narradores do autor. Funciona como uma espécie de porta-voz dos santos, transmitindo seus pensamentos, desgostos, alegrias, afeições, aspirações íntimas, narrando sempre do ponto de vista dos personagens. Sem qualquer ironia. (SILVA, 2002, p. 247)

É fato que os narradores das vidas de santos diferem das outras vozes narrativas dos mais distintos romances queirosianos, no entanto, isso pode revelar a flexibilidade estética de um autor capaz de escrever tanto romances em que figuram narradores muito ácidos e críticos às questões sociais, quanto remodelações hagiográficas, em que os recursos estilísticos da configuração dos narradores dialogam com características do gênero hagiográfico e nos dão notícias do íntimo de São Frei Gil, por exemplo. Entretanto, chamamos a atenção para a declaração de Silva, de que não há qualquer ironia nas reelaborações hagiográficas de Eça de Queirós. O que vimos, anteriormente, não corrobora a ideia de Silva, mas podemos ainda ir a outros trechos de "São Frei Gil", a fim de verificar se isso, com efeito, está em conformidade. Ainda no relato da doença de D. Abade, temos a seguinte informação: 
"Era no tempo dos figos - tendo demasiadamente comido d'esta fructa, o bom Abbade fôra atacado de um duro mal" (QUEIROZ, 1921, p. 308). Ora, a temática anticlerical de religiosos glutões é uma recorrência literária e cultural ${ }^{9}$, que remonta a uma longínqua tradição, conforme sugere Cristian Santos (2014, p. 58): “[...] a caricatura do clérigo obeso, apreciador da boa mesa, configurar-se-á em denúncia, não apenas no plano individual, como evidência da vida desregrada do clero, mas, principalmente, na esfera política, por exprimir privilégio outorgados à Igreja, por meio de alianças com o poder civil". Isto é, numa frase, que parece muito simples, cuja informação pode nos escapar, de primeira vista, há uma remissão crítica e recorrente aos religiosos e que não se limita a obra eciana. Portanto, a colocação de Silva, sobre não haver qualquer ironia na construção narrativa das vidas de santos, é falha.

No entanto, existem, igualmente, outras remissões em "São Frei Gil”, que apesar de sutis, desvelam o carácter crítico que podemos apreender da obra. Durante a viagem de D. Gil, com o seu escudeiro, Pero Malho, para Paris, o caminho passa a se mostrar hostil e inusitado:

\begin{abstract}
Sempre os mesmos rudes e estreitos caminhos, escavados pelo trilho das cavalgaduras, ou dos carros, se succediam, atravez de terras pobres, sem verdura e sem homens, d'uma côr secca de greda, com alguma arvore poeirenta [...]. Por vezes avistava uma pequena aldeia [...], agachada em torno de uma velha Egreja, meio arruinada, findando por uma taberna [...]. Gil desmontava ahi, fatigado; havia sempre algum frade mendicante, de aspecto torvo, bebendo o seu pichel de vinho [...]: e a taberna, os homens, toda a aldeia em redor, eram tão tristes, tão rudes, que Gil tornava a partir, preferindo dormir á beira da estrada / [...] Nas ermidas que topavam, encravadas entre fragas, os ermitões pareciam entontecidos pela velhice ou pela penitencia, recusavam abrigo aos cavalleiros ou fugiam para o alto do monte: - e nunca n'estas ermidas havia cruz ou imagem santa. Longos dias passado sem que encontrassem uma capella, um cruzeiro, onde se ajoelhassem, dissessem as suas rezas. [...] / - Meu bom Senhor, murmurava então Pero Malho, - nós vamos errando o caminho. / E succedia então que sempre algum pastor, ou frade mendicante, de barba revolta, ou caçador com a sua bésta ao hombro, surgia d'um vallado, ou d'entre rochas, e lhes affirmava sera aquella, bem direita, e bem certa, a estrada (QUEIROZ, 1921, p. 322-323)
\end{abstract}

As igrejas sem cruzes ou arruinadas ou mesmo a falta de cruzeiros na estrada remetem, obviamente, para o fato de que Gil se encaminha para o encontro com o

\footnotetext{
9 A título de curiosidade, podemos recordar que Eça de Queirós já havia tratado da temática da glutonaria clerical. $\mathrm{O}$ início de $\mathrm{O}$ crime do padre Amaro é um dos exemplos mais significativos dessa temática na escrita queirosiana, que se estende em muitas outras cenas do romance: "Foi no domingo de Páscoa que se soube em Leiria, que o pároco da Sé, José Migueis, tinha morrido de madrugada com uma apoplexia. O pároco era um homem [...] nutrido, que passava entre o clero diocesano pelo comilão dos comilöes. Contavam-se histórias singulares da sua voracidade. O Carlos da Botica - que o detestava - costumava dizer, sempre que o via sair depois da sesta, [...] muito enfartado: / - Lá vai a jibóia a esmoer. Um dia estoura! / Com efeito estourou, depois de uma ceia de peixe" (QUEIROZ, 2001, p. 7 , grifos do autor).
} 
Diabo, o que ocorrerá, com efeito. Mas pensemos em algumas questões bastante específicas do trecho transcrito: nas tabernas, Gil encontra frades bebendo e o aspecto desses religiosos é terrível. O jovem, a caminho de Paris, não encontra hospitalidade nas ermidas, em que os ermitões - espécie de ascetas e também religiosos - parecem estar atordoados. Quando Pero Malho desconfia da cilada do Diabo, sempre aparece, como que saído das rochas ou de alguma vala, alguém para afirmar que o caminho estava correto e, dentre essas figuras, a de um frade mendicante se faz presente. Vejamos, portanto, que o Diabo se traveste de religiosos nesta altura da narrativa. Seria muito inconsequente afirmar que o narrador está figurando os frades como representantes do maligno. Contudo, é possível afirmar, sem sombra de dúvidas, que o próprio Diabo, por vezes, aparece sob a roupagem do frade mendicante - que não é recluso a um mosteiro - ou do ermitão - de vida penitente e ascética. E, nesse caso, há remissões, ainda que subentendidas, ao anticlericalismo ou, para além, de que há religiosos a serviço do Maligno.

Se prosseguirmos com essas observações, chegaremos a outras descrições em que há menções a frades, como é o caso do encontro com a personagem Habrico, escudeiro do Senhor de Astorga, ambos como a personificação do ajudante e do Diabo, respectivamente: "[...] e um escudeiro, que, debruçado, desarrolhava uma garrafa que entalara entre os joelhos, voltou para os cavalleiros uma face estranha e grotesca, rapada como a d'um frade, com dois olhos negros que chammejavam" (QUEIROZ, 1921, p. 328, grifos nossos). Os termos que designam a face de Habrico são estranho e grotesco, mas há também a comparação desse rosto, repetimos, estranho e grotesco, com um frade imberbe. No momento da refeição, o próprio Senhor de Astorga é comparado a um frade glutão: "Ao enterrar a faca aguda no peito da perdiz, sorria, com os beiços lustrosos, como um frade guloso" (QUEIROZ, 1921, p. 331, grifos nossos).

A ironia e a crítica estão, portanto, presentes em "São Frei Gill". Ainda que de maneira sutil, as remissões aos religiosos, realizadas pelo narrador da obra, possuem referenciais reais no quotidiano português e no discurso anticlerical: a glutonaria fradesca e o mal, que poderia se apresentar sob os hábitos dos religiosos. Eça de Queirós, como podemos verificar, não havia se resignado completamente ou acatado os poderes estabelecidos: ferina, em poucos termos ou comparações, a ironia se desvela pela voz narrativa de uma das vidas de santo que o escritor reelaborou, além de estar em sintonia com as suas obras pregressas.

Maria Filomena Mónica, a título de curiosidade, relata como, de forma oportunista, o Estado Novo ${ }^{10}$ em Portugal também se valeu de alguns aspectos da interpretação distorcida da obra eciana para afirmações de cunho político:

\footnotetext{
${ }^{10}$ Entre os anos de 1933 e 1974, Portugal viveu sob o Estado Novo, uma Ditadura personalista, cujo agente mais importante foi António de Oliveira Salazar (1889-1970). De acordo com Daniel Melo (2013, p. 48), a grande ideologia do Regime se fazia, por meio dos discursos, "[...] consagrando a família, a tradição, a pátria e o catolicismo como elementos identitários do povo português [...] / Na concepção salazarista, a identidade do popular tem uma matriz rural evidente". Por esses motivos, quando se celebrou o centenário de Eça, houve a propagação do discurso de que, ao fim da vida, o autor foi um filho pródigo de volta às origens.
} 
Em 1945, ano do centenário do nascimento de Eça, os campos ideológicos extremaram-se. A esquerda, dominada pelos comunistas, privilegiou o Eça da juventude; a direita, comandada pelos próceres de Salazar, concentrou a sua admiração nas últimas obras. [...] / A cidade $e$ as serras acabou por se transformar no produto emblemático de um Estado, o Novo, que, sem escrúpulos, erigiu o livro como a obraprima de Eça. Segundo esta versão, na última fase da sua vida, o filho pródigo ter-se-ia reconciliado com Portugal. [...] O deslumbramento que Eça sentira diante de Paris poderia ter desaparecido. Mas isso não o fazia desejar Lisboa. Muito menos as montanhas. (MÓNICA, 2001, p. 435-436)

Eça de Queirós, um filho pródigo de retorno à casa pátria? Eça, um resignado? Eça, um reconciliado? A própria autora responde que não. Mónica menciona o romance $A$ cidade e as serras, mas o mesmo discurso, certamente, se aplicava às vidas de santos, sobretudo pelo teor religioso das narrativas e pelo período histórico em que foram escritas. O autor, portanto, não perdeu a sua visão crítica sobre Portugal, mas soube moldar a estilística de suas obras, passando a ser crítico não apenas com o seu país natal, mas também com a metrópole cultural europeia do século XIX: Paris.

Alguém, porventura, pode crer que a análise realizada no ensaio de Antonio Candido - e recordemos que o texto foi elaborado para o centenário de Eça estivesse em consonância com a divulgação de ideias que se fez acerca do autor português no período do Salazarismo. Entretanto, justiça seja feita, o próprio crítico brasileiro designou a propaganda salazarista como "[...] crítica simplista ou interessada" (CANDIDO, 1964, p. 56) e justificou em seu ensaio o seu posicionamento, que achamos por bem transcrever:

\footnotetext{
Não se queira atribuir a êste ensaio um critério estreitamente político, segundo o qual o autor acusasse a obra de Eça de Queirós pelo abandono da linha oposicionista, ou, ao contrário, louvasse-a pela adoção da linha compreensiva. Em crítica, os julgamentos de natureza política são dos mais arriscados, porque relegam o fenômeno literário para uma esfera inferior, confundindo os planos e nos expondo aos piores equívocos. Daí o perigo das interpretações de certa crítica portuguêsa, que se apoderou ùltimamente do recuo de Eça para explorá-lo com alvoroçada má fé. (CANDIDO, 1964, p. 54-55, grifos do autor)
}

O que assertivamente Candido recorda é que a interpretação do texto literário a serviço de um grupo político, olvida o trabalho estético e a análise necessários para que o grupo político enxergue no texto literário o que deseja ver, mas nem sempre o que ele traz, com efeito. Lúcido, Candido deixou claro o seu posicionamento, ao que nos parece, para também não ele ser referenciado como um polarizador de uma discussão que ele afirmava "[...] de ordem estética, não política" (CANDIDO, 1964, p. 55).

\section{CONSIDERAÇÕES FINAIS}


A leitura da apropriação de Eça de Queirós da lenda egidiana nos ajuda a compreender a complexidade desse escritor. Se, à primeira vista, pode parecer nada coerente que o ácido autor de $O$ crime do padre Amaro, de O primo Basílio ou de Os Maias escreva Vidas de Santos, o que percebemos é que Eça soube moldar a voz narrativa, a ambientação e figuração das personagens nessas diferentes composições literárias, revelando-se um exímio ficcionista.

"São Frei Gil", uma das obras dos últimos anos da vida do escritor, não é, todavia, a narrativa de um resignado ou de um reacionário sem o exercício da crítica: sutilmente, a ironia vem à baila e as pormenorizações da natureza e as descrições das tradições populares de Portugal não significam a aceitação completa dos poderes estabelecidos ou os louvores ao que considerava atrasado: são, na realidade, componentes importantíssimos dentro da obra que propôs elaborar.

Eça toma a lenda egidiana, calcada no medievo, para discutir as crises existenciais do ser humano moderno. "São Frei Gil" não é apenas um relato circunscrito na Idade Média, mas é, principalmente, a proposta de uma grande reflexão sobre a insatisfação humana. Para tanto, Eça usou da ironia, dialogou com as tradições hagiográficas e populares, criou pontes com os textos bíblicos e, embora a obra seja inacabada, o autor soube muito bem se valer da elaboração estética, que pode ser apreendida em pequenos detalhes, a fim de apresentar uma reflexão bastante pertinente sobre a vida humana. Assim, revelou-se um grande autor do Realismo, criticando os membros da instituição católica em uma "hagiografia" e, por isso, sendo crítico até mesmo ao gênero hagiográfico. $\mathrm{Na}$ sutileza da ironia, reside o autor verdadeiramente mordaz e não resignado.

\section{REFERÊNCIAS}

ALMEIDA, F. de. História da Igreja em Portugal. Tomo I. Porto: Portucalense Editora, 1967.

BERARDINELLI, C. Apresentação. In: QUEIRÓS, E. de. Vida de Santos: São Cristóvão - Santo Onofre - São Frei Gil. Rio de Janeiro: Casa da Palavra, 2002, p. 7-8.

BÍBLIA - Tradução Ecumênica da Bíblia. São Paulo: Loyola, 1995.

CANDIDO, A. Entre campo e cidade. In: CANDIDO, A. Tese e Antitese. São Paulo: Editora Nacional, 1964, p. 29-56.

ESPÍRITO SANTO, M. A religião popular portuguesa. Lisboa: Assírio \& Alvim, 1984. GAMBERINI, R. Poemas épicos e épico-históricos médio-latinos. In: ECO, U. (org.). Idade Média: Bárbaros, Cristãos e Muculmanos. Alfragide: Dom Quixote, 2016, p. 494-498.

GARRETT, A. Viagens na minha terra. Rio de Janeiro: Ediouro, 1977.

LICCIARDELLO, P. Gregório Magno e a Hagiografia. In: ECO, U. (org.). Idade Média: Bárbaros, Cristãos e Muçulmanos. Alfragide: Dom Quixote, 2016, p. 541-545. 
LOPO, R. Frei Gil de Santarém - servo de Deus ou do Diabo? - O catedrático do abismo. Centro Português de Investigação em História e Trabalho Social. Disponível em:

<http://www.cpihts.com/PDF09/frei\%20gil\%20vers\%C3\%A30\%20\%C3\%A9squil o.pdf $>$ Acesso em: 08 de Set. de 2019.

MATTOSO, J. Dois séculos de vicissitudes políticas. In: MATTOSO, J. (coord.). História de Portugal: A Monarquia Feudal (1096-1480): Segundo Volume. Lisboa: Editorial Estampa, 1999, p. 22-163

MELO, D. Salazarismo e Cultura Popular (1933-1958). Lisboa: Imprensa de Ciências Sociais, 2013.

MÓNICA, M. F. Eça: Vida e obra de José Maria Eça de Queirós. Rio de Janeiro: Record, 2001.

NERY, A. A. São Frei Gil (Eça de Queirós): entre a santidade e a "ambição de tudo saber”. Anais do XIII Congresso Internacional da ABRALIC: Internacionalização do Regional. Disponível em: <http://www.abralic.org.br/anais/arquivos/2013_1434328312.pdf> Acesso em: 08 de Set. de 2019.

QUEIRÓS, E. de. Vida de Santos: São Cristóvão - Santo Onofre - São Frei Gil. Rio de Janeiro: Casa da Palavra, 2002.

QUEIROZ, E. de. A cidade e as serras. Porto: Lello \& Irmão, 1945.

QUEIROZ, E. de. O crime do padre Amaro. São Paulo: Ediouro, 2001.

QUEIROZ, E. de. Ultimas Paginas (Manuscriptos Ineditos). Porto: Livraria Chardron, 1921.

SANTOS, C. J. O. Devotos e Devasso: Representação dos Padres e Beatas na Literatura Anticlerical Brasileira. São Paulo: EdUSP, 2014.

SILVA, S. S. e. As Lendas de Santos na obra de Eça de Queirós. In: QUEIRÓS, E. de. Vida de Santos: São Cristóvão - Santo Onofre - São Frei Gil. Rio de Janeiro: Casa da Palavra, 2002, p. 245-251.

STELLA, F. O maravilhoso na Literatura Medieval. In: ECO, U. (org.). Idade Média: Bárbaros, Cristãos e Muculmanos. Alfragide: Dom Quixote, 2016 p. 510-513.

/WATT, I. Mitos do Individualismo Moderno: Fausto, Dom Quixote, Dom Juan, Robinson Crusoé. Rio de Janeiro: Jorge Zahar Editor, 1997. 